\title{
Mnesic Imbalance and the Neuroanatomy of Autism Spectrum Disorders
}

\author{
Miguel Ángel Romero-Munguía \\ Hospital Psiquiátrico "Dr. Samuel Ramírez Moreno", Secretaría de Salud \\ México
}

\section{Introduction}

Currently, the diagnostic and statistical manual of the American Psychiatric Association (APA) defines autistic disorder together with Rett syndrome, childhood disintegrative disorder, Asperger syndrome and Pervasive Developmental Disorder Not Otherwise Specified (PDD-NOS) as Pervasive Developmental Disorders (APA, 2000). This term implies disorders that vary in several ways but the term Autism Spectrum Disorders (ASD), which excludes Rett syndrome and childhood disintegrative disorder, implies that there are shared clinical and etiological factors among diagnoses (Gabis et al., 2008). It has even been thought that the diagnosis of PDD-NOS, which does not require all three diagnostic symptoms of autism, does not deserve to be included as an ASD (Mercadante et al., 2006). On the other hand, the assumption of a normal early language development in Asperger syndrome has been challenged (Howlin, 2003).

Three major cognitive theories (theory of mind deficit, weak central coherence and executive dysfunction) have unsuccessfully attempted to explain the core triadic symptoms of ASD (impairments in social interaction, communicative capacity and behavioural flexibility) (Pisula, 2010). On the other hand, the mnesic imbalance theory seems to be a very promising solution to this problem. This account proposes that all three diagnostic symptoms of autism may be explained by an imbalance between a faulty procedural memory and a relatively preserved declarative memory (Romero-Munguía, 2008). The theory of mind is a system that enables one to infer mental states, central coherence is a tendency to create higher meanings from samples of data and the executive function is a set of mental processes that help us control our actions. Besides, it has recently been proposed that the alterations described by the three dominant theories can be explained by the mnesic imbalance theory. However, this theory can only be convincing if it is in accordance with data available from the neurobiological literature. In keeping with this view, this paper begins by reviewing the neurobiological basis of declarative and procedural memories. Next, it presents neuropathological, structural and functional imaging data of patients with ASD in order to support the mnesic imbalance theory.

\section{Memory systems}

Learning can be defined as a process for acquiring a behavioral change based on experience; this change is termed memory (Okano et al., 2000). Memory can be divided 
into declarative (explicit) and non-declarative (implicit) memory systems. Declarative memory can be subdivided into working memory, semantic memory and episodic memory, whereas non-declarative memory includes procedural memory, conditioned reflexes, emotional conditioning and priming. Declarative memory involves information that is subject to conscious recollection and verbal reflection, whereas procedural memory involves behavioural algorithms that operate at an unconscious level (Budson \& Price, 2001). Besides, lesions limited to the hippocampus, located within the medial temporal lobe, impair the acquisition of declarative knowledge sparing more remote declarative memory (Squire et al., 2004), whereas lesions limited to the cerebellum impair the acquisition of procedural knowledge, sparing more remote implicit knowledge (Bracha et al., 1997; Molinari et al., 1997; Quintero-Gallego et al., 2006). There are patients with severe deficits of declarative memory whose procedural memory is spared (Budson \& Price, 2001; Okano et al., 2000), while there are patients whose procedural learning is significantly below their declarative learning (Molinari et al., 1997; Quintero-Gallego et al., 2006). For instance, in a study utilizing the Serial Response Time Task (SRTT), a procedural learning task, the data suggest that in comparison with control group (C), children and adolescents with acquired pathology confined to the cerebellum (CE), and children and adolescents with additional damage due to the chemotherapy and radiotherapy used $(\mathrm{CE}+)$ had faulty procedural learning, while the California Verbal Learning Test (CVLT) was used to measure declarative learning, which was preserved in the two groups with cerebellar damage (Fig. 1).
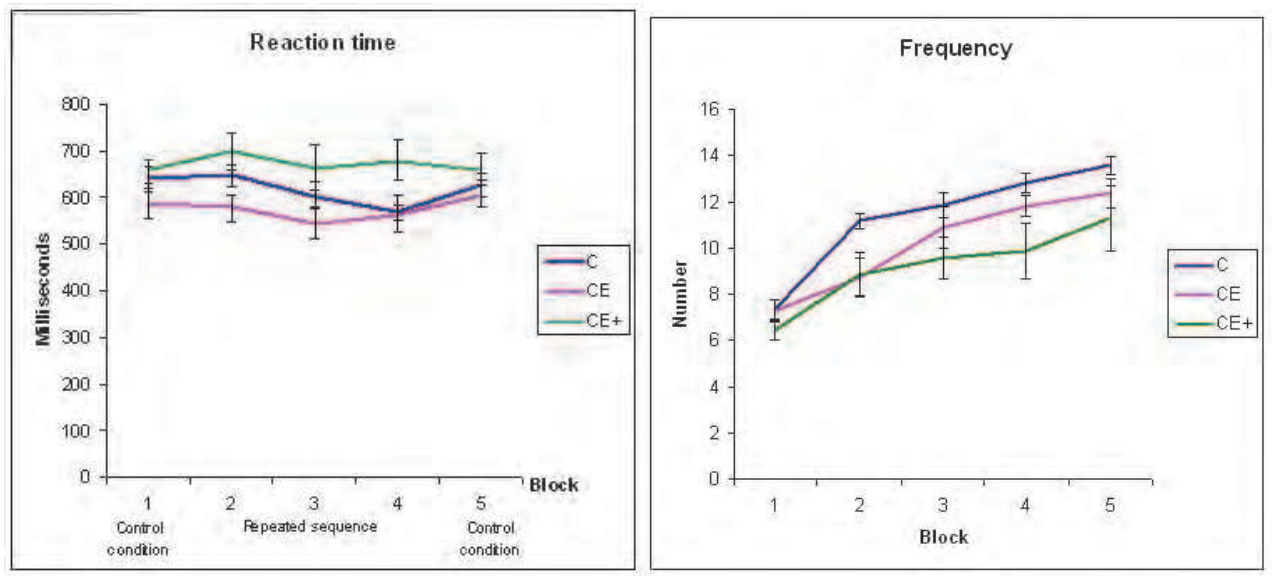

Fig. 1. Progressive reduction of reaction time during repeated sequence was an index of procedural learning, while the frequency of words remembered was an index of declarative learning. The standard error of measurement is also represented. (From Quintero-Gallego et al., 2006).

It is also important to note that there are neurobiological changes that occur with the development of memories in healthy human individuals. For instance, it is now accepted that neurogenesis occurs in the adult human hippocampus and it has been surmised that adding new neurons helps in acquiring new knowledge without disrupting knowledge that has already been stored (Appleby et al., 2011), whereas neurogenesis occurs in the human 
cerebellum mainly before the end of the first postnatal year, but its cytoarchitectonical development is completed subsequently (Ábrahám et al., 2001; Rakic \& Sidman, 1970). On the other hand, a postmortem study of persons who had developed a complex declarative memory showed significant reductions of minicolumnar width in six Brodmann areas (BA) of interests: primary motor cortex (BA 4), prefrontal association cortex (BA 9), primary visual cortex (BA 17), visual inferotemporal area (BA 21), higher order auditory cortex (BA 22), and parietal-temporal-occipital association cortex (BA 40) (Casanova et al., 2007). Furthermore, a three-dimensional magnetic resonance imaging study (Fig. 2) in people who had developed a complex procedural memory showed significant morphological enlargement in the vermal lobules VI-VII (declive, folium, and tuber), which might reflect an increased glial volume per purkinje cell, a larger volume of the molecular layer, a greater number of synapses, and/or a dendritic hypertrophy of stellate cells in the cerebellum (Park et al., 2009).
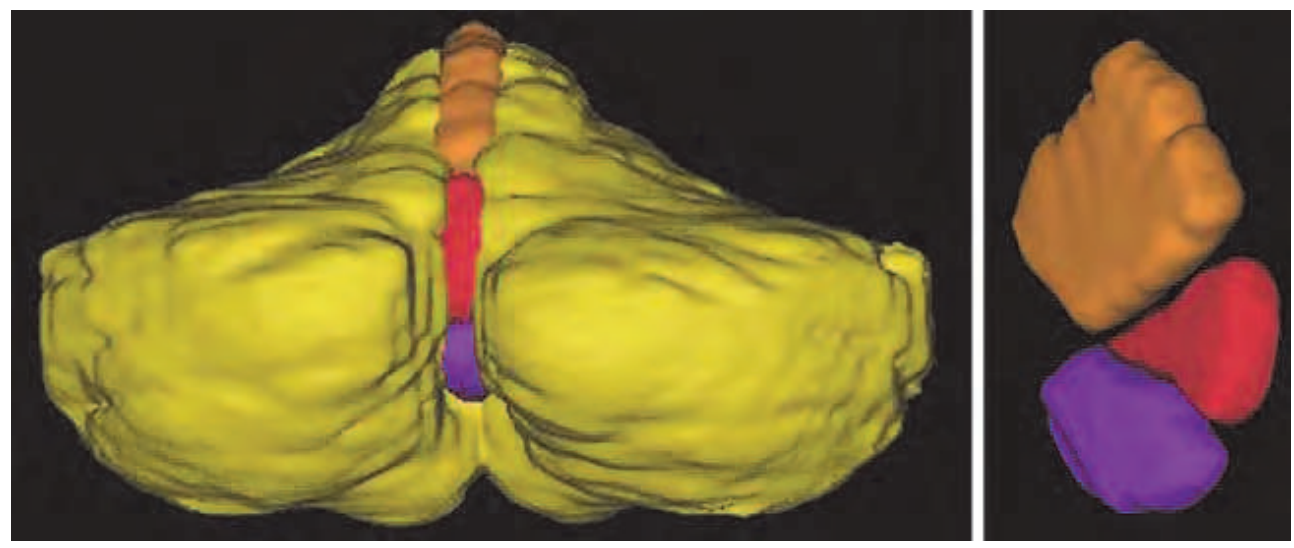

Fig. 2. 3-D model of the cerebellum. Yellow cerebellar hemisphere, orange vermian lobules IV, red vermian lobules VI-VII, purple vermian lobules VIII-X (From Park et al., 2009), with permission.

Several studies have shown that declarative learning results in gray matter changes. One of them demonstrates that students in intensive declarative learning showed a significant gray matter volume increase in the dorsomedial frontal cortex (DMPFC), the orbitofrontal cortex, and the precuneus (Ceccarelli et al., 2009). Furthermore, after a 3 month period of daily study sessions, students in extensive declarative learning showed a significant increase in gray matter volume in the posterior parietal cortex, inferior parietal cortex, and the hippocampus (Draganski et al., 2006). Another study has reported gray matter volume increases in temporal lobe, occipital lobe, inferior parietal lobe, middle frontal gyrus, and middle temporal gyrus after motor procedural learning, while individuals with procedural learning of motor sequences with objects had gray matter volume increases in the hippocampus; individuals with procedural learning of complex motor stereotypies had gray matter volume increases of the insula, and the inferior parietal lobe (Filippi et al., 2010).

Procedural learning is associated with changes in brain activation patterns, such as initial increases of activity in the prefrontal, bilateral somatosensory and parietal cortices, caudate nucleus and the ipsilateral cerebellar hemisphere. This activity progressively decreases 
during the subsequent acquisition of procedural knowledge, while there is an increase in activity in the cerebellar dentate, thalamus and putamen (Floyer-Lea \& Matthews, 2004). In another study, this process was divided into three distinct phases. A first phase, called the cognitive phase, has been associated with activation of the right frontal cortex (BA 10/11/45/46), right and left posterior cerebellum, left precuneus (BA 7/19), right angular region (BA 7/19/39), anterior cingulate cortex (ACC), and left frontal regions (BA 9/10). A second phase, called the associative phase, has shown bilateral activation of the lingual and calcarine regions (BA 17/18), right middle and right orbitofrontal region (BA 10/11/46), right thalamus and right caudate nucleus, left occipital region (BA 19), and right posterior cerebellum (Crus 1 and 2). A last phase, called the autonomous phase, has shown increased activity of the lingual and calcarine regions (BA 17/18), right anterior cerebellum (vermis VI-VII/hemisphere IV-VI), bilateral superior and middle frontal areas (BA 10/11) as well as the left thalamus (Hubert et al., 2007). In addition, data from an experimental study suggest that during procedural learning, cerebellar stimulation resulted in selective facilitation of contralateral excitability in the primary motor cortex, but it does not occur if procedural knowledge has already been acquired (Torriero et al., 2011). Similarly, if a stimulus to be stored into declarative memory occurs, then a period of increased activation will be produced in the dorsolateral prefrontal cortex (DLPFC), but there is a decrease in activation once the declarative knowledge has already been acquired (León-Carrión et al., 2010). The practice in working memory tasks is associated with progressive decrease of activation mainly in the right superior frontal gyrus/DLPFC (BA 8/9/46), the middle frontal gyrus bilaterally (BA 10/11), the left precentral gyrus (BA 4/6), and the dorsal part of the right ACC (BA 32), whereas there is a progressive increase of activation in the posterior cingulated cortex (PCC) adjacent to the corpus callosum (Koch et al., 2006). These temporal changes in neural activation might be linked to the efficiency of the declarative memory function; indeed, the activity of the posterior midline region, which includes PCC and precuneus, and the activity of the ventral part of lateral posterior parietal cortex, which includes the supramarginal gyrus and the angular gyrus, have shown reduced activity for hits relative to misses during encoding, whereas they showed increased activity for hits relative to misses during retrieval (Daselaar et al., 2009). Moreover, the lateral prefrontal cortex (LPFC) activity tends to increase with age, which is positively correlated with gains in declarative memory for details of experiences and reduction of gray matter volume in children and young adults, whereas medial temporal lobe activations appeared fully development by eight years of age (Ofen et al., 2007).

In functional magnetic resonance imaging, a number of studies have shown brain regions that are typically more active during resting states than during demanding cognitive tasks. This ensemble of cortical regions is called the default mode network (DMN) and it has been observed that DMN regions are not only more strongly deactivated with a higher cognitive load relative to a lower cognitive load during a short-term memory (working memory) task, but also the activation of the DMN is more pronounced at rest after a cognitively challenging task relative to an easier task, as illustrated in Fig. 3 (Pyka et al., 2009). In addition, DMN functional connectivity is progressively increased in the medial prefrontal cortex (MPFC) regions and progressively decreased in PCC regions when moving from lower to higher short-term declarative memory loads (Esposito et al., 2009).

In the first clinical description of children with autism, Kanner wrote, referring to their excellent declarative memory, "It is difficult to know for certain whether the stuffing as such 


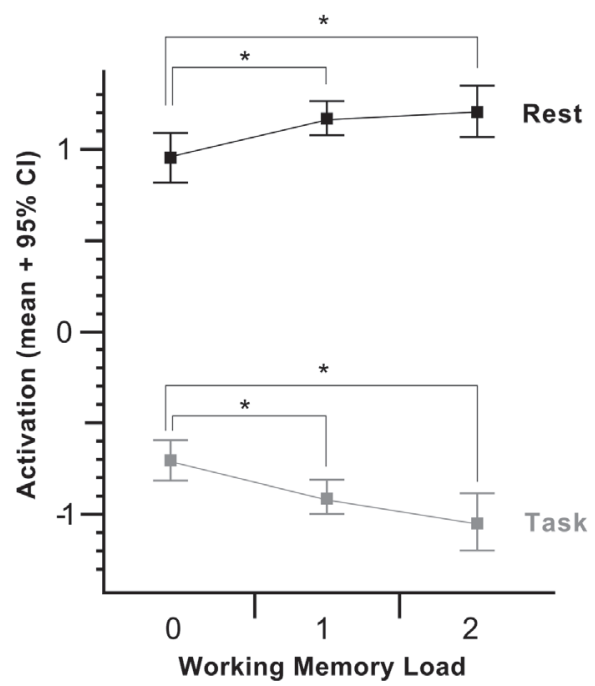

Fig. 3. Means for activation in the DMN were calculated for each n-back (lower values: 0back, 1-back, 2-back) and subsequent resting block (upper values: R0-back, R1-back, R2back) x-Axis; working memory load, y-Axis (From Pyka et al., 2009).

has contributed essentially to the course of the psychopathologic condition" (Kanner, 1943). Thereafter, the notion of faulty procedural memory that is compensated for by relatively preserved declarative memory has been proposed as an account of the savant abilities, as well as of the symptoms in autism (Goldberg, 1987; Klinger et al., 2007; Mostofsky et al., 2000; Romero-Munguía, 1998, 2002, 2008). For instance, in a study utilizing the Behavioral Summarized Evaluation (BSE) to evaluate autistic symptomatology in children with autistic disorder with non-functional verbal language (NFV) or no spoken language (NSL), as well as children with mixed receptive-expressive language disorder (RLD). All participants solved tests for reception of gestural language (Ges), vocabulary (Voc), and verbal commands (Com). A significant procedural knowledge deficit and a significant positive correlation between autism symptoms and declarative knowledge were observed only among the overall group of children with autistic disorder, which indicates an imbalance between declarative and procedural memory in autism rather than mere faulty procedural memory, as suggested in Fig. 4 (From Romero-Munguía, 2002).

However, in recent studies the view of a procedural learning deficit has been challenged (Barnes et al., 2008; Brown et al., 2010, Nemeth et al., 2010), but this discrepancy seems to be more apparent than real, because each author may be referring to different types of memories although using the same terms (Romero-Munguía, 2009). For instance, papers that supports the mnesic imbalance theory have been described as being based on a general deficit in implicit learning (Brown et al., 2010), but this is inaccurate because procedural memory is only one type of implicit memory (Budson \& Price, 2001). Indeed, papers that argue against the presence of faulty implicit learning have shown significant decreases in reaction time, but this was independent of learning about sequences (Barnes et al., 2008; Brown et al., 2010, Nemeth et al., 2010), which suggests any other type of preserved implicit learning rather than intact procedural learning (Budson \& Price, 2001); however, 


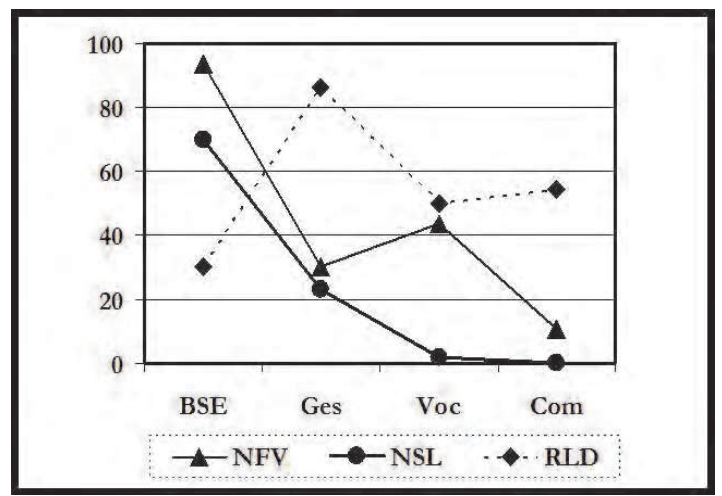

Fig. 4. Percent of the highest score achieved by any participant on every test, $x$-Axis; the reception of gestural language was an index of procedural knowledge, while the reception of vocabulary was an index of declarative knowledge, y-Axis (From Romero-Munguía, 2002).

interestingly, it has been surmised that this faster reaction time may imply an enhancement of declarative (explicit) memory in autism (Gidley Larson \& Mostofsky, 2008; Molinari et al., 1997; Walenski et al., 2008). Nevertheless, it is important to note that the present paper does not suggest that procedural learning is entirely absent in autism, but rather its development is significantly lower in comparison to declarative learning (Gordon \& Stark, 2007; RomeroMunguía, 2008).

According to the mnesic imbalance theory, a cerebellar maldevelopment may cause faulty procedural memory, as with relatively intact declarative memory as well as a reciprocal causal interaction, in which some neuroanatomical changes might result from this mnesic imbalance (Romero-Munguía, 2007). New information has appeared that has increased knowledge of how this interaction may occur; the present paper is devoted to this matter.

\section{Neurobiological findings in autism}

At present, it is difficult to avoid the view that a single cognitive theory can explain neither the neurobiological heterogeneity nor the core triadic symptoms of ASD (Pisula, 2010; Rajendran \& Mitchell, 2007; Waterhouse, 2008). However, this section offers arguments based on neurobiological findings in favor of the mnesic imbalance theory.

\subsection{Neuropathological findings}

Purkinje cells are the only output neurons of the cerebellar cortex and loss of them within the cerebellum is the most replicated finding (72\%) according to a review on the neuropathology of autism (Palmen, 2004). Indeed, some of the negative cases included in that review might be false negatives. For instance, a study included a case with encephalopathy of phenylketonuria (Williams et al., 1980), and other case could be diagnosed as childhood disintegrative disorder (APA, 2000; Guerin et al., 1996); both disorders may mimic ASD. In a study of six cases, five cases had low Purkinje cell counts, but one did not. However, only in that case, eosinophilic inclusions in the perikaryon and proximal dendrites of $30-40 \%$ of Purkinje cells were seen in the cerebellar vermis; they were less frequent in the cerebellar hemispheres, and they were not observed elsewhere (Bailey et 
al., 1998). These inclusions might have been associated with cerebellar dysfunction. Moreover, basket and stellate cells (GABAergic interneurons) in the molecular layer of the cerebellar cortex may influence the output of Purkinje cells (Bao et al., 2010; Rancillac \& Crépel, 2004), so the increase in GAD67 mRNA levels in cerebellar interneurons of persons with ASD might be related to Purkinje cell dysfunction (Yip et al., 2008).

Abnormally enlarged neurons have been observed in the inferior olive of the brainstem in young individuals with autism, whereas these neurons are small and pale in adults with autism (Bauman \& Kemper, 2005), which might be explained by the need to keep the scant procedural knowledge that has been acquired. This assumption is in agreement with experimental observations involving stimulation of the nucleo-olivary pathway just before an unconditioned stimulus, which leads to extinction of the conditioned response (Bengtsson et al., 2007), hence, an interruption in this pathway might prevent procedural memory loss, but this disruption of neuronal signal to the inferior olive may lead to its hypertrophy, as well as to olivary atrophy after several years (Akar et al., 2008).

A subgroup of individuals with ASD has an apparently normal early development, followed by a loss of verbal and/or non-verbal skills prior to 2 years of age. Such a regression has been found in $30 \%$ of children with autistic disorder, whereas it has been found in $14 \%$ of those with PDD-NOS, and none with Asperger syndrome (Meilleur \& Fombonne, 2009). A study found that children with autistic regression show more frequent use of words and babble compared with typical infants at 12 months of age (Werner \& Dawson, 2005). This might be explained by assuming that basket and stellate cells established precocious synaptic contacts which could improve the procedural learning, although thereafter, an increased number of interneurons relative to Purkinje cells could impair this procedural learning. This hypothesis is in accordance with the report of autistic cases with a lower density of Purkinje cells in comparison to cerebellar interneurons (Whitney et al., 2009). In addition, it has been suggested that during the normal development of the human cerebellum, granule cells influence the survival of interneurons, they regulate their migration to the molecular layer, and induce their differentiation into basket and stellate cells after birth, whereas before birth Purkinje cells would induce differentiation of granular layer interneurons, as proposed in Fig. 5 (Leto et al., 2008). The aforementioned might be clinically relevant because the source of cerebellar granule cells is exclusively the external granular layer, which disappears between the end of the first and the second postnatal year (Ábrahám et al.,, 2001; Rakic \& Sidman, 1970), hence a delay in the disappearance of external granular layer might cause the autistic regression since a reduced density of Purkinje cells in presence of a normal or high density of cerebellar interneurons has been reported in at least two of six autistic cases (Whitney et al., 2009). The latter might be associated with dysfunctional synaptic transmission between cerebellar interneurons and Purkinje cells.

The aforementioned review reported increased cell packing density, reduced cell size, and simplified dendritic pattern in the hippocampus in $64 \%$ of cases with autism (Palmen, 2004). According to the mnesic imbalance theory, declarative memory replaces faulty procedural memory in some of its functions in individuals with ASD, which implies an overload for the declarative memory (Romero-Munguía, 2008). Therefore, it is necessary to use a best adaptation strategy, and additive neurogenesis seems better than either conventional synaptic plasticity or neuronal turnover (Appleby et al., 2011),, so this best strategy might lead to the particularly large number of likely immature cells (newly born neurons) depicted 

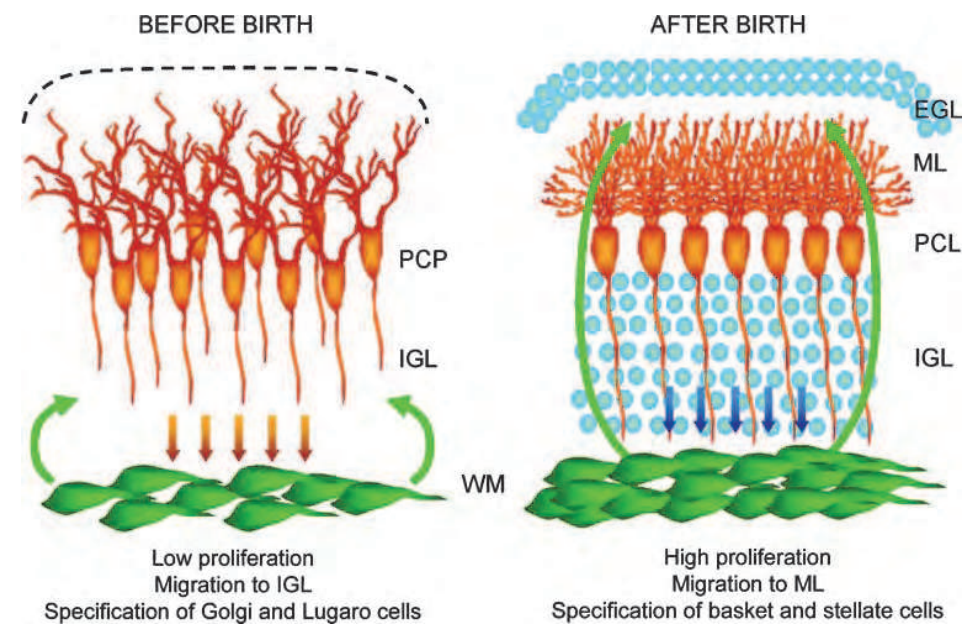

Fig. 5. Schematic illustration of the hypothesis that neurons adjacent to the prospective white matter influence the fate choices of interneuron precursors during prenatal and postnatal cerebellar development. PCP Purkinje cell plate, WM white matter, IGL internal granular layer, $P C L$ Purkinje cell layer, $M L$ molecular layer, EGL external granular layer (From Leto et al., 2008), with permission.

above. Indeed, an increased cell packing density (minicolumns per cortical area) with reduced cell size also has been reported in several areas of the cerebral cortex of non-autistic individuals with complex declarative memory, as well as of individuals with ASD (Casanova, 2007; Casanova et al., 2007). The possibility that the human neocortex produces neurons after birth has been suggested (Gould, 2007). Likewise, increased microglial cell density has been reported in gray matter of the DLPFC of patients with autism compared to control cases (Morgan et al., 2010); activity in DLPFC has been associated with declarative memory (Galea et al., 2010; Koch et al., 2006; León-Carrión et al., 2010). In addition, physiological stimuli such as environmental enrichment and physical activity lead to production of new glial cells (Ehninger \& Kempermann, 2003). Therefore, it is possible that an overload for the declarative memory is related to an increase in this type of cells. Furthermore, contrary to other disorders involving mental retardation, which are associated with loss of dendritic spines, higher spine densities were found in temporal (BA 21), frontal (BA 9), and parietal (BA 7) lobes of autistic patients who had suffered moderate to severe mental retardation, as suggested in Fig. 6 (Hutsler \& Zhang, 2010), that is, in some cerebral cortical regions that have been associated with complex declarative memory (Casanova et al., 2007).

\subsection{Structural neuroimaging}

A meta-analysis of structural magnetic resonance imaging studies from over 800 individuals with autism reported generalized enlargement of cerebral hemispheres, cerebellum and caudate nucleus, whereas reductions in the size were observed in corpus callosum, vermal lobules VIII-X, midbrain, and vermal lobules VI-VII; a normalization in the size of vermal lobules VI-VII with increasing age was also reported (Stanfield et al., 2008). The latter is consistent with a more recent analysis of abnormality in vermis lobules VI-VII, as shown in Fig. 7 (Courchesne et al., 2011). This increase in vermis size might be a consequence of the 


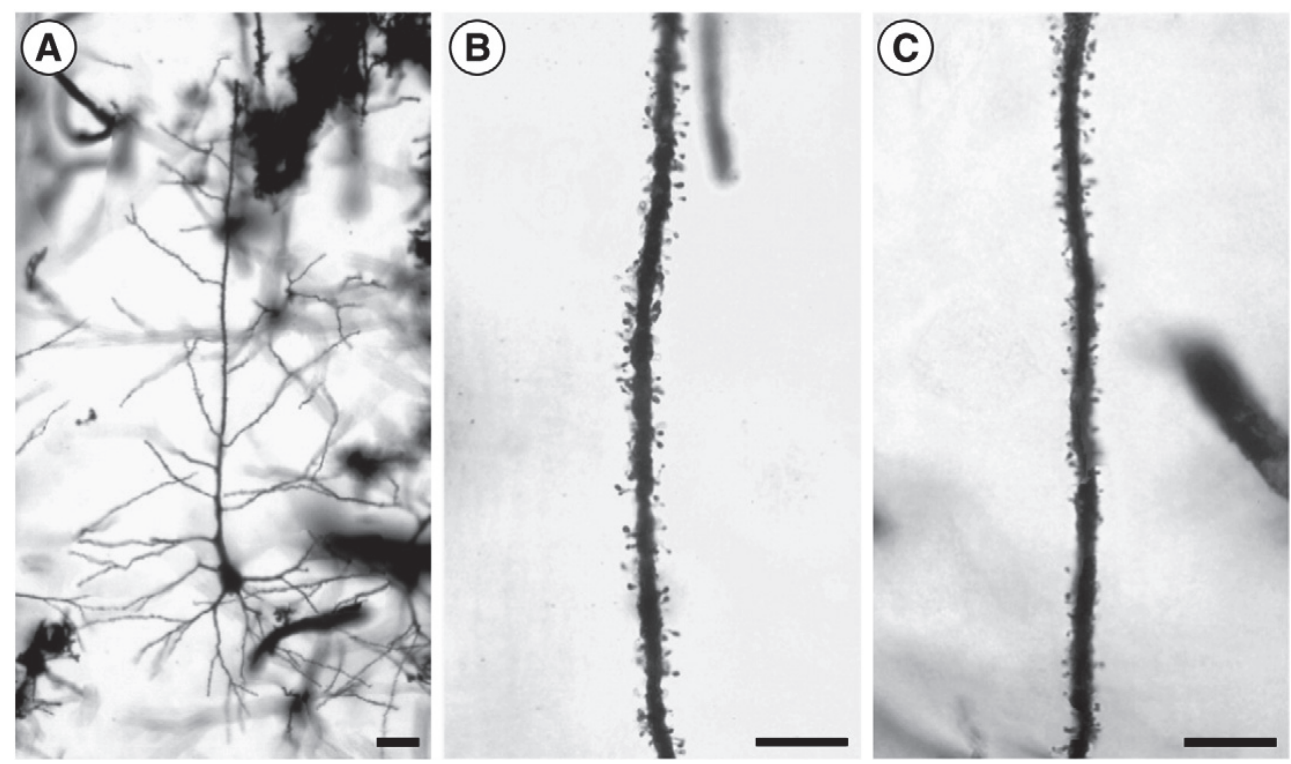

Fig. 6. (A) An example of a Golgi-impregnated pyramidal cell in layer III of the superior frontal gyrus (BA 9) in an ASD case. (B and C) Apical dendrite segments showing spine densities of layer V pyramidal cells in BA 9 of ASD (B) and control subjects (C). Both examples are approximately $300 \mu \mathrm{m}$ from the cell soma. Scale bar in $A=25 \mu \mathrm{m}$; Scale bars in B and C $=20 \mu \mathrm{m}$ (From Hutsler \& Zhang, 2010), with permission.

slow development of procedural memory, a hypothesis that is consistent with previous research and the mnesic imbalance theory (Gordon \& Stark, 2007; Park et al., 2009; RomeroMunguía, 2008).

A volumetric analysis of the cerebellum in children and adolescents with ASD showed that total vermis volume was decreased in ASD, but when the ASD groups were examined separately, only the children and adolescents with higher functioning autism showed a statistically significant smaller volume of the vermis, compared with that of the typically developing controls. However, the data showed a trend towards a larger midsagittal area of vermal lobules VI-VII of individuals with higher functioning autism, compared with individuals with lower functioning autism, as well as with Asperger syndrome. This suggests a smaller vermal width in people with higher functioning autism (Scott et al, 2009). A previous study found a similar trend towards a larger midsagittal area of vermal lobules VI-VII of preschool children with higher functioning autism, compared with that of preschool children with lower functioning autism (Akshoomoff et al., 2004). Therefore, a larger midsagittal area of vermal lubules might be the vestige of an enlargement in vermal lobules VI-VII that could improve the procedural learning (Park et al., 2009), although thereafter, the lobules might show a decrease in volume without damaging remote procedural knowledge (Bracha et al., 1997; Molinari et al., 1997; Quintero-Gallego et al., 2006). In addition, an inverse correlation between the area of cerebellar vermis lobules VIVII and frontal gray matter was found in preschool children with autistic disorder (Carper \& Courchesne, 2000). In concordance with this, a study of monozygotic twins 


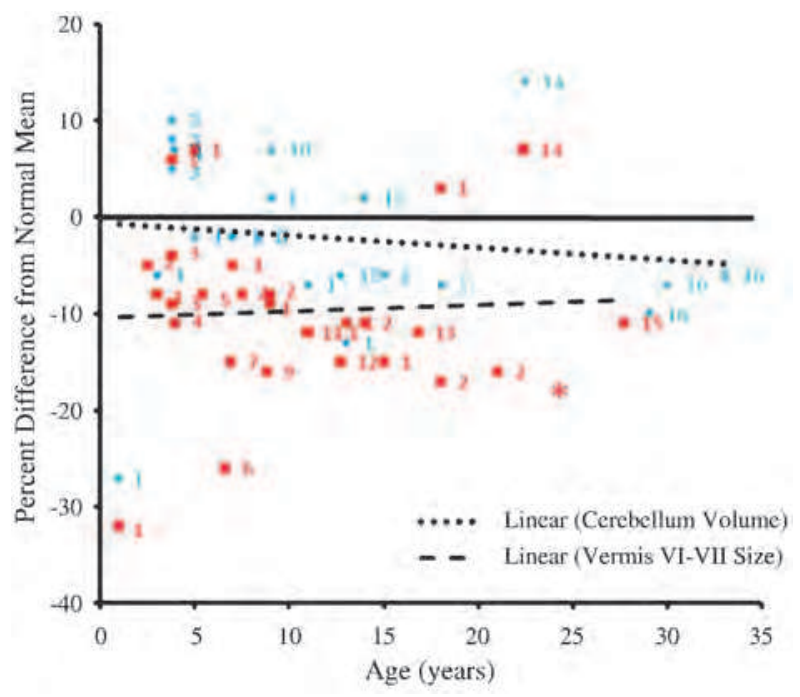

Fig. 7. Cerebellum and vermis size from infancy to adulthood in autism. Percent differences from normal average in each study of autistic subjects are plotted for cerebellar volume (blue diamonds) and vermis lobule VI-VII cross-sectional area (red squares) against age. Regression lines are shown for cerebellar volume and vermis lobule VI-VII area. The solid line represents normal average. Each number represents a separate study that has been cited in the paper from where this figure has been obtained (From Courchesne et al, 2011), with permission.

discordant for autism reported that DLPFC, amygdala, and vermal lobules VI-VII volumes were significantly associated with the severity of autistic symptomatology based on scores from the Autism Diagnostic Observation Schedule-Generic (Mitchell et al., 2009). All these findings are in accordance with the proposal of overload for declarative memory (Galea et al., 2010; Koch et al., 2006; León-Carrión et al., 2010), as well as faulty procedural memory (Hubert et al., 2007; Park et al., 2009). On the other hand, brain overgrowth is most pronounced in the frontal and temporal lobes; this occurs in people with ASD mainly during the first four years of life, but it is followed by arrest of growth, as illustrated in Fig. 8 (Courchesne et al., 2011). According to the mnesic imbalance theory, an overload for declarative memory might lead to a particularly precocious brain growth that is followed by a precocious arrest of growth (Romero-Munguía, 2007, 2008).

A recent study has estimated that cortical thickness provided the best classification between adults with ASD and controls: a pattern of reduced gray matter in frontal regions and increased gray matter in temporal regions (Ecker et al., 2010). This pattern resembles an exaggeration of the typical development of declarative memory in the human brain (Ceccarelli et al., 2009; Ofen et al., 2007). Another study has reported significant correlations between the volumes of the caudate, frontal lobe, temporal lobe, cerebellum and a measure of repetitive behaviors, while social and communication deficits in autism were associated with caudate, cerebellar, precuneus, frontal and temporal lobe regional volumes (Rojas et al., 2006). The overload for the declarative memory, as well as procedural learning of sequences and stereotypies might lead to these regional gray matter volumetric changes in autism (Ceccarelli et al., 2009; Draganski et al., 2006; Filippi et al., 2010). Moreover, a study involving 


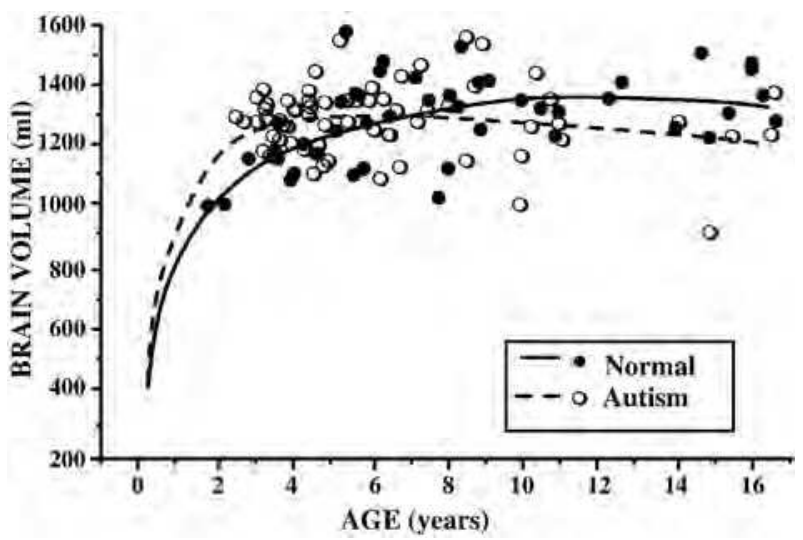

Fig. 8. Brain growth in autism through 16 years. Data plot shows larger MRI-based volumes in autistic 2- to 4-year-old males as compared to normal 2- to 4-year-old males and smaller overall brain volumes in autistic 8-16 year olds as compared to normal (From Courchesne et al, 2011), with permission.

boys with high-functioning autism compared to boys with developmental disorder reported that radiate but not deep white matter volume is increased in autism (Herbert, 2005). This might imply not only local over-connectivity, but also long-distance disconnection in the frontal lobe, as well as in other lobes (Courchesne \& Pierce, 2005). All of this is in accordance with the assumption that a faulty procedural memory may complicate the simultaneous application of procedural knowledge (Romero-Munguía, 2008). So for instance, a study of children with autism showed that greater gray matter volume was associated with better communication skills in several regions of the frontal lobe, whereas increased total gray matter volume was correlated with more severe symptoms of autism (Parks et al., 2009); another study has reported that amygdala enlargement is correlated with better joint attention ability at age 4 years in children with autism (Mosconi et al., 2009), whereas this amygdala enlargement has been associated with more severe social and communication impairments in toddlers with autism (Schumann et al., 2009). However, the relationship between neuroanatomy and symptoms may be different across ASD due to cognitive differences among patients with low-functioning autism, high-functioning autism, and Asperger syndrome. So, the presence of a history of early speech delay in autistic disorder may reflect a greater deficit of procedural memory, compared with that in Asperger syndrome, which may lead to greater overload for declarative memory that might lead to an increase in gray matter that is smaller in Asperger syndrome (Ceccarelli et al., 2009; Draganski et al., 2006; Toal et al., 2010), while in high-functioning autism, the cerebral gray matter volume might have a negative correlation, not only with performance IQ but also with gains in declarative memory for details of experiences (Lotspeich et al., 2004; Ofen et al., 2007).

\subsection{Functional neuroanatomy}

The mnesic imbalance theory suggests a significantly slow development of procedural learning in ASD (Gordon \& Stark, 2007; Romero-Munguía, 2008), which must be in accordance with data available on functional neuroanatomy of ASD. So for instance, in a 
study utilizing functional magnetic resonance imaging, the data showed that in comparison with the control group, adults with high-functioning autism had increased activity in the primary somatosensory cortex and the primary motor cortex during the late stages of a procedural learning task (Müller et al., 2004), which suggest a delay in procedural learning (Floyer-Lea \& Matthews, 2004; Torriero et al., 2011). In another study, regional cerebral blood flow was measured in men with high-functioning autism during an emotionrecognition task, the results showed higher regional cerebral blood flow in the right anterior temporal lobe, ACC and right thalamus in individuals with autism (Hall et al., 2003); that is, the autistic group has shown activity of the first phases of procedural learning whereas the control group has shown activity of its last phase (Hubert et al., 2007). A study found that in comparison with the control group, males with high-functioning autism had diffusely increased connectivity of the caudate nuclei during simple visuomotor coordination tasks (Turner et al., 2006); an experimental study showed that during procedural learning, the striatum (caudate nucleus and putamen) has a diffuse functional connectivity, but this is selective if procedural knowledge has already been acquired (Barnes et al., 2005). Furthermore, the mnesic imbalance theory suggests that procedural memory is required to infer what a person is feeling from the facial expression, or some other perceptual category (Romero-Munguía, 2008); hence its deficit might lead to the utilization of alternate neural pathways dedicated to that task. For instance, a study examined whether successful facial affect recognition training is associated with increased activation of the fusiform gyrus in autism. Trained participants showed behavioral improvements with higher activity in the superior parietal lobe and maintained activation in the occipital cortex, but no significant activation changes in the fusiform gyrus were shown (Bölte et al., 2006). In contrast, the results of a study involving expert and novices radiologists during the interpreting of radiographic images, suggest that the fusiform gyrus becomes more engaged and the occipital cortex less engaged in interpreting radiographic images over the course of training (Harley et al., 2009).

Studies of the DMN in autism show several abnormalities. One of them demonstrated that ASD subjects fail to show the deactivation effect (Kennedy et al., 2006). The overload for the declarative memory might explain the fail to show the deactivation effect in ASD because the activation of the DMN is more pronounced at rest, after a cognitively challenging task (Pyka et al., 2009). In addition, the mnesic imbalance theory has argued that persons with ASD use explicit mental representations to resolve systemizing problems, while normally developing individuals do not (Romero-Munguía, 2008; Sahyoun et al., 2010). These explicit mental representations might not only prevent the deactivation effect but also increasing the activation of the DMN since the DMN is significantly activated during mental imagery (Daselaar et al., 2010). Other studies have observed decreased functional connectivity between posterior regions of DMN and other regions (Assaf et al., 2010; Monk et al., 2009). This might also be explained by overload for the declarative memory because DMN functional connectivity is progressively decreased in PCC regions during high short-term declarative memory loads (Esposito et al., 2009). In addition, association between delays in the decrease of amygdala activity and the reduction in the number of errors during a second set of facial recognition memory task was observed in adults with ASD, which was not present in healthy comparison subjects (Kleinhans et al, 2009). Albeit, a previous study reported that increased amygdala activation is associated with better face memory performance in healthy individuals (Kleinhans et al., 2007). Moreover,a significant increase 
of choline/creatine and a significant decrease of $\mathrm{N}$-acetyl-aspastate/creatine in the hippocampus and amygdala was observed in children with ASD (Gabis et al., 2008), while in another study healthy elderly subjects had these same results at the hippocampus after they completed declarative memory training (Valenzuela et al, 2003). Finally, it is interesting to note that the disruption of the DLPFC improves the consolidation of procedural knowledge (Galea et al., 2010), which might shed light on its preliminary results in ASD (Baruth et al., 2010; Sokhadze et al., 2010).

\section{Conclusion}

The mnesic imbalance theory surmises that a cerebellar dysfunction causes faulty procedural memory with relatively intact declarative memory, as well as a reciprocal causal interaction, in which some neuroanatomical changes may result from this mnesic imbalance. The present work has offered arguments based on neurobiological findings in favour of this cognitive theory.

\section{Acknowledgment}

The author would like to thank Edith Monroy for reviewing the language of the manuscript.

\section{References}

Ábrahám, H.; Tornóczky, T.; Kosztolányi, G. \& Seress, L. (2001). Cell formation in the cortical layers of the developing human cerebellum. International journal of developmental neuroscience, Vol. 19, No. 1, pp. 53-62, ISSN: 0736-5748.

Akar, S.; Drappatz, J.; Hsu, L.; Blinder, R.A.; Black, P.M. \& Kesari, S. (2008). Hypertrophic olivary degeneration after resection of a cerebellar tumor. Journal of neuro-oncology, Vol. 87, No. 3, pp. 341-345. ISSN: 1573-7373.

Akshoomoff, N.; Lord, C.; Lincoln, A.J.; Courchesne, R.Y.; Carper, R.A.; Townsend, J. \& Courchesne, E. (2004). Outcome classification of preschool children with autism spectrum disorders using MRI brain measures. Journal of the American Academy of Child and Adolescent Psychiatry, Vol. 43, No. 3, pp. 349-357, ISSN: 1527-5418.

American Psychiatric Association. (2000). Diagnostic and statistical manual of mental disorders (4th edition, text revision), American Psychiatric Publishing, ISBN: 978-0890420256, Washington, DC.

Appleby, P.A.; Kempermann, G. \& Wiskott, L. (2011). The role of additive neurogenesis and synaptic plasticity in a hippocampal memory model with grid-cell like input. PLoS computational biology, Vol. 7, No. 1, pp. e1001063, ISSN: 1553-7358.

Assaf, M.; Jagannathan, K.; Calhoun, V.D.; Miller, L.; Stevens, M.C.; Sahl, R.; O'Boyle, J.G.; Schultz, R.T. \& Pearlson, G.D. (2010). Abnormal functional connectivity of default mode sub-networks in autism spectrum disorder patients. NeuroImage, Vol. 53, No. 1, 247-256, ISSN: 1095-9572.

Bailey, A.; Luthert, P.; Dean, A.; Harding, B.; Janota, I.; Montgomery, M.; Rutter, M. \& Lantos, P. (1998). A clinicopathological study of autism. Brain : a journal of neurology, Vol. 121, No. 5, pp. 889-905, ISSN: 0006-8950. 
Bao, J.; Reim, K. \& Sakaba. T. (2010). Target-dependent feedforward inhibition mediated by short-term synaptic plasticity in the cerebellum. The Journal of neuroscience, Vol. 30, No. 24, pp. 8171-8179, ISSN: 1563-5279.

Barnes, T.D.; Kubota, Y.; Hu, D.; Jin, D.Z. \& Graybiel, A.M. (2005). Nature, Vol. 437, No. 7062, pp. 1158-1161, ISSN: 1476-4687.

Barnes, K.A.; Howard, J.H. Jr.; Howard, D.V.; Gilotty, L.; Kenworthy, L.; Gaillard, W.D. \& Vaidya, C.J. (2008). Intact implicit learning of spatial context and temporal sequences in childhood autism spectrum disorder. Neuropsychology, Vol. 22, No. 5, pp. 563-570, ISSN: 1931-1559.

Baruth, J.M.; Casanova, M.F.; El-Baz, A.; Horrell, T.; Mathai, G.; Sears, L. \& Sokhadze, E. (2010). Low-Frequency Repetitive Transcranial Magnetic Stimulation (rTMS) Modulates Evoked-Gamma Frequency Oscillations in Autism Spectrum Disorder (ASD). Journal of neurotherapy, Vol. 14, No. 3, pp. 179-194, ISSN: 1530-017X.

Bauman, M.L. \& Kemper, T.L. (2005). Neuroanatomic observations of the brain in autism: a review and future directions. International journal of developmental neuroscience, Vol. 23, No. 2-3, pp. 183-187, ISSN: 0736-5748.

Bengtsson, F.; Jirenhed, D.A.; Svensson, P. \& Hesslow, G. (2007). Extinction of conditioned blink responses by cerebello-olivary pathway stimulation. Neuroreport, Vol. 18, No.14, pp. 1479-1482, ISSN: 1473-558X.

Bölte, S.; Hubl, D.; Feineis-Matthews, S.; Prvulovic, D.; Dierks, T. \& Poustka, F. (2006). Facial affect recognition training in autism: can we animate the fusiform gyrus? Behavioral neuroscience, Vol. 120, No. 1, pp. 211-216, ISSN: 1939-0084.

Bracha, V.; Zhao, L.; Wunderlich, D.A.; Morrissy, S.J. \& Bloedel, J.R. (1997).Patients with cerebellar lesions cannot acquire but are able to retain conditioned eyeblink reflexes. Brain : a journal of neurology, Vol. 120, No. 8, pp. 1401-1413, ISSN: 00068950 .

Brown, J.; Aczel, B.; Jiménez, L.; Kaufman, S.B. \& Grant, K.P. (2010). Intact implicit learning in autism spectrum conditions. The quarterly journal of experimental psychology, Vol. 63, No. 9, pp. 1789-1812, ISSN: 1747-0226.

Budson, A.E. \& Price, B.H. (2001). Memory: clinical disorders. In: Nature encyclopedia of life sciences, Vol. 11, Nature Publishing Group. (Ed.), pp. 529-536, Macmillan Publishers Ltd,London, UK. Available from http://people.bu.edu/abudson/budson-memory.pdf

Carper, R.A. \& Courchesne, E. (2000). Inverse correlation between frontal lobe and cerebellum sizes in children with autism. Brain : a journal of neurology, Vol. 123, No. 4, pp. 836-844, ISSN: 0006-8950.

Casanova, M.F. (2007). The neuropathology of autism. Brain pathology, Vol. 17, No.4, pp.422433, ISSN: $1750-3639$.

Casanova, M.F.; Switala, A.E.; Trippe, J. \& Fitzgerald, M. (2007). Comparative minicolumnar morphometry of three distinguished scientists. Autism : the international journal of research and practice, Vol. 11, No. 6, pp. 557-569, ISSN: 1461-7005.

Ceccarelli, A.; Rocca, M.A.; Pagani, E.; Falini, A.; Comi, G. \& Filippi, M. (2009). Cognitive learning is associated with gray matter changes in healthy human individuals: a tensor-based morphometry study. NeuroImage, Vol. 48, No. 3, pp. 585-589, ISSN:1095-9572. 
Courchesne, E. \& Pierce, K. (2005). Why the frontal cortex in autism might be talking only to itself: local over-connectivity but long-distance disconnection. Current opinion in neurobiology, Vol. 15, No. 2, pp. 225-230, ISSN: 1873-6882.

Courchesne, E.; Campbell, K. \& Solso, S. (2011). Brain growth across the life span in autism: Age-specific changes in anatomical pathology. Brain research, Vol. 1380, pp. 138-45, ISSN: 1872-6240.

Daselaar, S.M.; Prince, S.E.; Dennis, N.A.; Hayes, S.M.; Kim, H. \& Cabeza, R. (2009). Posterior midline and ventral parietal activity is associated with retrieval success and encoding failure. Frontiers in human neuroscience, Vol. 3, pp. e13, ISSN: 16625161.

Daselaar, S.M.; Porat, Y.; Huijbers, W. \& Pennartz, C.M. (2010). Modality-specific and modality-independent components of the human imagery system. NeuroImage, Vol. 52, No. 2, pp. 677-685, ISSN: 1095-9572.

Draganski, B.; Gaser, C.; Kempermann, G.; Kuhn, H.G.; Winkler, J.; Büchel, C. \& May, A. (2006). Temporal and spatial dynamics of brain structure changes during extensive learning. The Journal of neuroscience: the official journal of the Society for Neuroscience,Vol. 26, No. 23, pp. 6314-6317, ISSN: 1529-2401.

Ecker, C.; Marquand, A.; Mourão-Miranda, J.; Johnston, P.; Daly, E.M.; Brammer, M.J.; Maltezos, S.; Murphy, C.M.; Robertson, D.; Williams, S.C. \& Murphy, D.G. (2010). Describing the brain in autism in five dimensions--magnetic resonance imagingassisted diagnosis of autism spectrum disorder using a multiparameter classification approach. The Journal of neuroscience: the official journal of the Society for Neuroscience, Vol. 30, No. 32, pp. 10612-10623, ISSN: 1529-2401.

Ehninger, D. \& Kempermann, G. (2003). Regional effects of wheel running and environmental enrichment on cell genesis and microglia proliferation in the adult murine neocortex. Cerebral cortex, Vol. 13, No. 8, pp. 845-851, ISSN: 1460-2199.

Esposito, F.; Aragri, A.; Latorre, V.; Popolizio, T.; Scarabino, T.; Cirillo, S.; Marciano, E.; Tedeschi, G. \& Di Salle, F. (2009). Does the default-mode functional connectivity of the brain correlate with working-memory performances? Archives italiennes de biologie, Vol. 147, No. 1-2, pp. 11-20, ISSN: 0003-9829.

Filippi, M.; Ceccarelli, A.; Pagani, E.; Gatti, R.; Rossi, A.; Stefanelli, L.; Falini, A.; Comi, G. \& Rocca, M.A. (2010). Motor learning in healthy humans is associated to gray matter changes: a tensor-based morphometry study. PloS one, Vol. 5, No. 4, pp. e10198, ISSN: 1932-6203.

Floyer-Lea, A. \& Matthews, P.M. (2004). Changing brain networks for visuomotor control with increased movement automaticity. Journal of neurophysiology, Vol.92, No. 4, pp. 2405-2412, ISSN: 1522-1598.

Gabis, L.; Huang, W.; Azizian, A.; Devincent, C.; Tudorica, A.; Kesner-Baruch, Y.; Roche, P. \& Pomeroy, J. (2008). 1H-magnetic resonance spectroscopy markers of cognitive and language ability in clinical subtypes of autism spectrum disorders. Journal of child neurology, Vol. 23, No. 7, pp. 766-774, ISSN: 1708-8283.

Galea, J.M.; Albert, N.B.; Ditye, T. \& Miall, R.C. (2010). Disruption of the dorsolateral prefrontal cortex facilitates the consolidation of procedural skills. Journal of cognitive neuroscience, Vol. 22, No. 6, pp. 1158-1164, ISSN: 1530-8898.

Gidley Larson, J.C. \& Mostofsky, S.H. (2008). Evidence that the pattern of visuomotor sequence learning is altered in children with autism. Autism research : official journal 
of the International Society for Autism Research, Vol. 1, No. 6, pp. 341-353, ISSN: 19393806.

Goldberg, T.E. (1987). On hermetic reading abilities. Journal of autism and developmental disorders, Vol. 17, No. 1, pp. 29-44, ISSN: 1573-3432.

Gordon, B. \& Stark S. (2007). Procedural Learning of a Visual Sequence in Individuals with Autism. Focus on autism and other developmental disabilities, Vol.22, No. 1, pp. 14-22, ISSN: 1088-3576.

Gould, E. (2007). How widespread is adult neurogenesis in mammals? Nature reviews. Neuroscience, Vol. 8, No. 6, pp. 481-488, ISSN: 1471-0048.

Guerin, P.; Lyon, G.; Barthelemy, C.; Sostak, E.; Chevrollier, V.; Garreau, B. \& Lelord, G. (1996). Neuropathological study of a case of autistic syndrome with severe mental retardation. Developmental medicine and child neurology, Vol. 38, No. 3, pp. 203-211, ISSN: 0012-1622.

Hall, G.B.; Szechtman, H. \& Nahmias, C. (2003). Enhanced salience and emotion recognition in Autism: a PET study. The American journal of psychiatry, Vol. 160, No. 8, pp. 14391441, ISSN: 1535-7228.

Harley, E.M.; Pope, W.B.; Villablanca, J.P.; Mumford, J.; Suh, R.; Mazziotta, J.C.; Enzmann, D. \& Engel S.A. (2009). Engagement of fusiform cortex and disengagement of lateral occipital cortex in the acquisition of radiological expertise. Cerebral cortex, Vol. 19, No. 11, pp. 2746-2754, ISSN: 1460-2199.

Herbert, M.R. (2005). Large brains in autism: the challenge of pervasive abnormality. The Neuroscientist : a review journal bringing neurobiology, neurology and psychiatry, Vol. 11, No. 5, pp. 417-440, ISSN: 1089-4098.

Howlin, P. (2003). Outcome in high-functioning adults with autism with and without early language delays: implications for the differentiation between autism and Asperger syndrome. Journal of autism and developmental disorders, Vol. 33, No. 1, pp. 3-13, ISSN: 1573-3432.

Hubert, V.; Beaunieux, H.; Chételat, G.; Platel, H.; Landeau, B. ; Danion, J.M. ; Viader, F. ; Desgranges, B. \& Eustache, F. (2007). The dynamic network subserving the three phases of cognitive procedural learning. Human brain mapping, Vol.28, No.12, pp.1415-1429, ISSN: 1097-0193.

Hutsler, J.J. \& Zhang, H. (2010). Increased dendritic spine densities on cortical projection neurons in autism spectrum disorders. Brain research, Vol. 1309, pp. 83-94, ISSN: $1872-6240$.

Kanner, L. (1943). Autistic disturbances of affective contact. The nervous child, Vol. 2, pp. 217250, ISSN: 0099-4286.

Kennedy, D.P.; Redcay, E. \& Courchesne, E. (2006). Failing to deactivate: resting functional abnormalities in autism. Proceedings of the National Academy of Sciences of the United States of America, Vol. 103, No. 21, pp. 8275-8280, ISSN: 1091-6490.

Kleinhans, N.M.; Johnson, L.C.; Mahurin, R.; Richards, T.; Stegbauer, K.C.; Greenson, J.; Dawson, G. \& Aylward, E. (2007). Increased amygdala activation to neutral faces is associated with better face memory performance. Neuroreport, Vol. 18, No. 10, 987991, ISSN: 1473-558X.

Kleinhans, N.M.; Johnson, L.C.; Richards, T.; Mahurin, R.; Greenson, J.; Dawson, G. \& Aylward, E. (2009). Reduced neural habituation in the amygdala and social 
impairments in autism spectrum disorders. The American journal of psychiatry, Vol. 166,No. 4, pp. 467-475, ISSN: 1535-7228.

Klinger, L.G.; Klinger, M.R. \& Pohlig, R. (2007). Implicit learning impairments in autism spectrum disorders: Implications for treatment. In: New developments in autism: The future is today, Pérez, J.M.; González, P.M.; Comí, M.L. \& Nieto, C. (Eds.), pp. 76103, Jessica Kingsley Publishers, ISBN: 978-1-84310-449-0, London, UK.

Koch, K.; Wagner, G.; von Consbruch, K.; Nenadic, I.; Schultz, C.; Ehle, C.; Reichenbach, J.; Sauer, H. \& Schlösser, R. (2006). Temporal changes in neural activation during practice of information retrieval from short-term memory: an fMRI study. Brain research, Vol. 1107, No. 1, pp. 140-150, ISSN: 1872-6240.

León-Carrión, J.; Izzetoglu, M.; Izzetoglu, K.; Martín-Rodríguez, J.F.; Damas-López, J.; Barroso y Martin, J.M. \& Domínguez-Morales, M.R. (2010). Efficient learning produces spontaneous neural repetition suppression in prefrontal cortex. Behavioural brain research, Vol. 208, No. 2, pp. 502-508, ISSN: 1872-7549.

Leto, K.; Bartolini, A. \& Rossi, F. (2008). Development of cerebellar GABAergic interneurons: origin and shaping of the "minibrain" local connections. The cerebellum, Vol. 7, No. 4, pp. 523-529, ISSN: 1473-4230.

Lotspeich, L.J.; Kwon, H.; Schumann, C.M.; Fryer, S.L.; Goodlin-Jones, B.L.; Buonocore, M.H.; Lammers, C,R.; Amaral, D.G. \& Reiss, A.L. (2004). Investigation of neuroanatomical differences between autism and Asperger syndrome. Archives of general psychiatry, Vol. 61, No. 3, pp. 291-298, ISSN: 1538-3636.

Meilleur, A.A. \& Fombonne, E. (2009). Regression of language and non-language skills in pervasive developmental disorders. Journal of intellectual disability research, Vol. 53, No. 2, pp. 115-124, ISSN: 1365-2788.

Mercadante, M.T.; Van der Gaag, R.J. \& Schwartzman, J.S. (2006). Non-Autistic Pervasive Developmental Disorders: Rett's syndrome, childhood disintegrative disorder and pervasive developmental disorder not otherwise specified. Revista brasileira de psiquiatria, Vol. 28, Suppl. 1, pp. 12-20, ISSN: 1809-452X.

Mitchell SR, Reiss AL, Tatusko DH, Ikuta I, Kazmerski DB, Botti JA, Burnette CP, Kates WR. (2009). Neuroanatomic alterations and social and communication deficits in monozygotic twins discordant for autism disorder. The American journal of psychiatry, Vol. 166, No. 8, pp. 917-925, ISSN: 1535-7228.

Molinari, M.; Leggio, M.G.; Solida, A.; Ciorra, R.; Misciagna, S.; Silveri, MC. \& Petrosini, L. (1997). Cerebellum and procedural learning: evidence from focal cerebellar lesions. Brain : a journal of neurology, Vol. 120, No. 10, pp. 1753-1762, ISSN: 1460-2156.

Monk, C.S.; Peltier, S.J.; Wiggins, J.L.; Weng, S.J.; Carrasco, M.; Risi, S. \& Lord, C. (2009). Abnormalities of intrinsic functional connectivity in autism spectrum disorders. NeuroImage, Vol. 47, No. 2, pp. 764-772, ISSN: 1095-9572.

Morgan, J.T.; Chana, G.; Pardo, C.A.; Achim, C.; Semendeferi, K.; Buckwalter, J.; Courchesne, E. \& Everall, I.P. (2010). Microglial activation and increased microglial density observed in the dorsolateral prefrontal cortex in autism. Biological psychiatry, Vol. 68, No. 4, pp. 368-376, ISSN: 1873-2402.

Mosconi, M.W.; Cody-Hazlett, H.; Poe, M.D.; Gerig, G.; Gimpel-Smith, R. \& Piven, J. (2009). Longitudinal study of amygdala volume and joint attention in 2- to 4-year-old children with autism. Archives of general psychiatry, Vol. 66, No. 5, pp. 509-516, ISSN: 1538-3636. 
Mostofsky, S.H.; Goldberg, M.C.; Landa R.J. \& Denckla M.B. (2000). Evidence for a deficit in procedural learning in children and adolescents with autism: implications for cerebellar contribution. Journal of the International Neuropsychological Society, Vol. 6, No. 7, pp. 752-759, ISSN: 1469-7661.

Müller, R.A.; Cauich, C.; Rubio, M.A.; Mizuno, A. \& Courchesne, E. (2004). Abnormal activity patterns in premotor cortex during sequence learning in autistic patients, Biological psychiatry, Vol. 56, No. 5, pp. 323-332, ISSN: 1873-2402.

Nemeth, D.; Janacsek, K.; Balogh, V.; Londe, Z.; Mingesz, R.; Fazekas, M.; Jambori, S.; Danyi, I. \& Vetro, A (2010). Learning in autism: implicitly superb. PloS one, Vol. 5, No. 7, pp. 11731, ISSN: 1932-6203.

Ofen, N.; Kao, Y.C.; Sokol-Hessner, P.; Kim, H.; Whitfield-Gabrieli, S. \& Gabrieli, J.D. (2007). Development of the declarative memory system in the human brain. Nature neuroscience, Vol. 10, No. 9, pp. 1198-1205, ISSN: 1546-1726.

Okano, H.; Hirano, T. \& Balaban, E. Learning and memory. (2000). Proceedings of the National Academy of Sciences of the United States of America, Vol. 97, No. 23, pp. 12403-12404, ISSN: 1091-6490.

Park, I.S.; Lee, K.J.; Han, J.W.; Lee, N.J.; Lee, W.T.; Park, K.A. \& Rhyu, I.J. (2009). Experiencedependent plasticity of cerebellar vermis in basketball players. The cerebellum, Vol. 8, No. 3, pp. 334-339, ISSN: 1473-4230.

Parks, L.K.; Hill, D.E.; Thoma, R.J.; Euler, M.J.; Lewine, J.D. \& Yeo, R.A. (2009). Neural correlates of communication skill and symptom severity in autism: A voxel-based morphometry study. Research in Autism Spectrum Disorders, Vol. 3, No. 2, pp. 444454, ISSN: $1750-9467$.

Pisula, E. (2010). The autistic mind in the light of neuropsychological studies. Acta neurobiologiae experimentalis, Vol. 70, No. 2, pp. 119-130, ISSN: 1689-0035.

Pyka, M.; Beckmann, C.F.; Schöning, S.; Hauke, S.; Heider, D.; Kugel, H.; Arolt, V. \& Konrad, C. (2009). Impact of working memory load on FMRI resting state pattern in subsequent resting phases. PloS one, Vol. 4, No. 9, pp. e7198, ISSN: 1932-6203.

Quintero-Gallego, E.A.; Gómez, C.M.; Vaquero Casares, E.; Márquez, J. \& Pérez-Santamaría, F.J. (2006). Declarative and procedural learning in children and adolescents with posterior fossa tumours. Behavioral and brain functions, Vol. 2, No. 1, pp. e9, ISSN: 1744-9081.

Rojas, D.C.; Peterson, E.; Winterrowd, E.; Reite, M.L.; Rogers, S.J. \& Tregellas J.R. (2006). Regional gray matter volumetric changes in autism associated with social and repetitive behavior symptoms. BMC psychiatry, Vol. 6, pp. e56, ISSN: 1471-244X.

Rajendran, G. \& Mitchell, P. (2007). Cognitive Theories of Autism. Developmental Review, Vol. 27, No. 2, pp. 224-260, ISSN: 0273-2297.

Rancillac, A. \& Crépel, F. (2004). Synapses between parallel fibres and stellate cells express long-term changes in synaptic efficacy in rat cerebellum. The Journal of physiology, Vol. 554, No. 3, pp. 707-720. ISSN: 1469-7793.

Rakic, P. \& Sidman, R.L. (1970). Histogenesis of cortical layers in human cerebellum, particularly the lamina dissecans. Journal of comparative neurology and psychology, Vol. 139, No. 4, pp. 473-500, ISSN: 0021-9967.

Romero-Munguía, M.A. (1998). ¿Es la memoria procesal deficiente la causa del comportamiento estereotipado en el autismo? Psiquiatría, Órgano Oficial de Difusión de la Asociación Psiquiátrica Mexicana, A.C., Vol. 14, No. 2 pp. 62-65, ISSN: 0187-4543. 
Romero-Munguía, M.A. (2002). Memoria procesal deficiente y alteraciones de la comunicación en la patogenia del autismo infantil. Neurología, Neurocirugía y Psiquiatría, Vol. 35, No. 4, pp.203-208, ISSN: 0028-3851.

Romero-Munguía, M.A. (2007). Sistemas de memoria y neuroanatomía en los trastornos del espectro autista, In: Psiquiatría y Neurociencias, Castro-Román, R. \& VelázquezMoctezuma, J. (Eds.), pp. 247-276, Hospital Psiquiátrico "Dr. Samuel Ramírez Moreno" - Universidad Autónoma Metropolitana, ISBN: 978-970-31-0983-8, México, DF.

Romero-Munguía, M.A. (2008). Mnesic imbalance: a cognitive theory about autism spectrum disorders. Annals of general psychiatry, Vol. 7, No. 1, pp. e20, ISSN: 1744-859X.

Romero-Munguía, M.A. (2009). Trastorno de aprendizaje no verbal frente a trastorno del espectro autista: el papel del aprendizaje procesal. Revista de Neurología, Vol. 49, No. 8, pp. 448, ISSN: 1576-6578.

Sahyoun, C.P.; Belliveau, J.W.; Soulières, I.; Schwartz, S. \& Mody, M. (2010). Neuroimaging of the functional and structural networks underlying visuospatial vs. linguistic reasoning in high-functioning autism. Neuropsychologia, Vol . 48, No. 1, pp. 86-95, ISSN: 1873-3514.

Schumann, C.M.; Barnes, C.C.; Lord, C. \& Courchesne, E. (2009). Amygdala enlargement in toddlers with autism related to severity of social and communication impairments. Biological psychiatry, Vol. 66, No. 10, pp. 942-949, ISSN: 1873-2402.

Scott, J.A.; Schumann, C.M.; Goodlin-Jones, B.L. \& Amaral, D.G. (2009). A comprehensive volumetric analysis of the cerebellum in children and adolescents with autism spectrum disorder. Autism research : official journal of the International Society for Autism Research, Vol. 2, No. 5, pp. 246-257, ISSN: 1939-3806.

Sokhadze, E.; Baruth, J.; Tasman, A.; Mansoor, M.; Ramaswamy, R.; Sears, L.; Mathai, G.; ElBaz, A. \& Casanova, M.F. (2010). Low-frequency repetitive transcranial magnetic stimulation (rTMS) affects event-related potential measures of novelty processing in autism. Applied psychophysiology and biofeedback, No. 35, No. 2, pp. 147-161, ISSN: 1573-3270.

Squire, L.R.; Stark, C.E. \& Clark, R.E. (2004). The medial temporal lobe. Annual review of neuroscience, Vol. 27, pp. 279-306, ISSN: 1545-4126.

Stanfield, A.C.; McIntosh, A.M.; Spencer, M.D.; Philip, R.; Gaur, S. \& Lawrie, S.M. (2008). Towards a neuroanatomy of autism: a systematic review and meta-analysis of structural magnetic resonance imaging studies. European psychiatry : the journal of the Association of European Psychiatrists, Vol. 23, No. 4, pp. 289-299, ISSN: 1778-3585.

Toal, F.; Daly, E.M.; Page, L.; Deeley, Q.; Hallahan, B.; Bloemen, O.; Cutter, W.J.; Brammer, M.J.; Curran, S.; Robertson, D.; Murphy, C.; Murphy, K.C. \& Murphy, D.G. (2010). Clinical and anatomical heterogeneity in autistic spectrum disorder: a structural MRI study. Psychological medicine, Vol. 40, No. 7, pp. 1171-1181, ISSN: 1469-8978.

Torriero, S.; Oliveri, M.; Koch, G.; Lo Gerfo, E.; Salerno, S.; Ferlazzo, F.; Caltagirone, C. \& Petrosini, L. (2011). Changes in cerebello-motor connectivity during procedural learning by actual execution and observation. Journal of cognitive neuroscience, Vol. 23, No. 2, pp. 338-348, ISSN: 1530-8898.

Turner, K.C.; Frost, L.; Linsenbardt, D.; Mcllroy, J.R. \& Müller, R.A. (2006). Atypically diffuse functional connectivity between caudate nuclei and cerebral cortex in autism. Behavioral and brain functions, Vol. 2, No. 1, pp. e34, ISSN: 1744-9081. 
Valenzuela MJ, Jones M, Wen W, Rae C, Graham S, Shnier R, Sachdev P. (2003). Memory training alters hippocampal neurochemistry in healthy elderly. Neuroreport, Vol. 14, No. 10, pp. 1333-1337, ISSN: 1473-558X.

Walenski, M.; Mostofsky, S.H.; Gidley-Larson, J.C. \& Ullman M.T (2008). Brief report: enhanced picture naming in autism. Journal of autism and developmental disorders, Vol. 38, No. 7, pp.1395-1399, ISSN: 1573-3432.

Waterhouse, L. (2008). Autism overflows: increasing prevalence and proliferating theories. Neuropsychology review, Vol. 18, No. 4, pp. 273-286, ISSN: 1573-6660.

Werner, E. \& Dawson, G. (2005). Validation of the phenomenon of autistic regression using home videotapes. Archives of general psychiatry, Vol. 62, No. 8, pp. 889-895, ISSN: 1538-3636.

Whitney, E.R.; Kemper, T.L.; Rosene, D.L.; Bauman, M.L. \& Blatt, G.J. (2009). Density of cerebellar basket and stellate cells in autism: evidence for a late developmental loss of Purkinje cells. Journal of neuroscience research, Vol. 87, No. 10, pp. 2245-2254, ISSN: 1097-4547.

Williams, R.S.; Hauser, S.L.; Purpura, D.P.; DeLong, G.R. \& Swisher, C.N. (1980). Autism and mental retardation: neuropathologic studies performed in four retarded persons with autistic behavior. Archives of neurology, Vol. 37, No. 12, pp. 749-753, ISSN: 0003-9942.

Yip, J.; Soghomonian, J.J. \& Blatt, G.J. (2008). Increased GAD67 mRNA expression in cerebellar interneurons in autism: implications for Purkinje cell dysfunction. Journal of Neuroscience Research, Vol. 86, No. 3, pp. 525-530, ISSN: 1097-4547. 


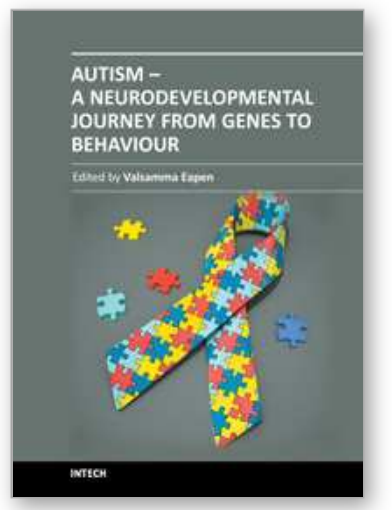

\author{
Autism - A Neurodevelopmental Journey from Genes to Behaviour \\ Edited by Dr. Valsamma Eapen
}

ISBN 978-953-307-493-1

Hard cover, 484 pages

Publisher InTech

Published online 17, August, 2011

Published in print edition August, 2011

The book covers some of the key research developments in autism and brings together the current state of evidence on the neurobiologic understanding of this intriguing disorder. The pathogenetic mechanisms are explored by contributors from diverse perspectives including genetics, neuroimaging, neuroanatomy, neurophysiology, neurochemistry, neuroimmunology, neuroendocrinology, functional organization of the brain and clinical applications from the role of diet to vaccines. It is hoped that understanding these interconnected neurobiological systems, the programming of which is genetically modulated during neurodevelopment and mediated through a range of neuropeptides and interacting neurotransmitter systems, would no doubt assist in developing interventions that accommodate the way the brains of individuals with autism function. In keeping with the multimodal and diverse origins of the disorder, a wide range of topics is covered and these include genetic underpinnings and environmental modulation leading to epigenetic changes in the aetiology; neural substrates, potential biomarkers and endophenotypes that underlie clinical characteristics; as well as neurochemical pathways and pathophysiological mechanisms that pave the way for therapeutic interventions.

\title{
How to reference
}

In order to correctly reference this scholarly work, feel free to copy and paste the following:

Miguel Angel Romero-Munguia (2011). Mnesic Imbalance and the Neuroanatomy of Autism Spectrum Disorders, Autism - A Neurodevelopmental Journey from Genes to Behaviour, Dr. Valsamma Eapen (Ed.), ISBN: 978-953-307-493-1, InTech, Available from: http://www.intechopen.com/books/autism-aneurodevelopmental-journey-from-genes-to-behaviour/mnesic-imbalance-and-the-neuroanatomy-of-autismspectrum-disorders

\section{INTECH}

open science | open minds

\section{InTech Europe}

University Campus STeP Ri

Slavka Krautzeka 83/A

51000 Rijeka, Croatia

Phone: +385 (51) 770447

Fax: +385 (51) 686166

www.intechopen.com

\section{InTech China}

Unit 405, Office Block, Hotel Equatorial Shanghai

No.65, Yan An Road (West), Shanghai, 200040, China

中国上海市延安西路 65 号上海国际贵都大饭店办公楼 405 单元

Phone: +86-21-62489820

Fax: $+86-21-62489821$ 
(C) 2011 The Author(s). Licensee IntechOpen. This chapter is distributed under the terms of the Creative Commons Attribution-NonCommercialShareAlike-3.0 License, which permits use, distribution and reproduction for non-commercial purposes, provided the original is properly cited and derivative works building on this content are distributed under the same license. 